\title{
MEMBANGUN KARAKTER MAHASISWA BERBASIS NILAI-NILAI PANCASILA SEBAGAI RESOLUSI KONFLIK
}

\author{
Oleh : \\ Supriyono
}

Universitas Pendidikan Indonesia

Email : prima_java@yahoo.co.id

\begin{abstract}
Condition of Indonesia is now being hit by a climate of character which does not support the output of Pancasila culture. The waning of characters can be seen from the number of people taking drugs, fighting between the village and the school, consumerist lifestyle, which is concerned with the practice of religious life and the juridical formalism symbols that make it easy to competed. The crisis of character now has spread on campus so easily found student attitudes and behaviors that conflict with moral values.

As a man who respects the harmony and compatibility of national identity as it is appropriate if the values of Pancasila moral values to serve as a foundation to live a life of society, nation and state. Ethical principles of Pancasila intrinsically humanistic, meaning that the values of Pancasila based on values rooted in the dignity of man as a being cultured. Pancasila as the state ideology of the nation and contain values of divinity , human values, the value of unity, democratic values and the values of justice. If people are able to realize and really be able to run five moral rules or values contained in the fifth Pancasila, then humans can save the nation from various conflicts . Building character through the values of Pancasila can unite the entire diversity of Indonesia .
\end{abstract}

Keywords : Character, values of Pancasila, and Conflict Resolution

Abstrak, Kondisi bangsa Indonesia sekarang sedang dilanda oleh sebuah iklim karakter kehidupan yang tidak mendukung tumbunya budaya Pancasila. Memudarnya karakter dapat dilihat dari banyaknya orang mengkonsumsi narkoba, tawuran antar kampung dan sekolah, pola hidup konsumeris, praktik hidup keagamaan yang mementingkan formalisme yuridis dan simbol-simbol yang memudahkan untuk diadu domba. Krisis karakter sekarang ini sudah menjalar pada lingkungan kampus sehingga mudah ditemui sikap dan perilaku mahasiswa yang bertentangan dengan nilai moral.

Sebagai manusia yang menjunjung keharmonisan dan keserasian sebagai jati diri bangsa maka sangatlah tepat jika nilai-nilai Pancasila dijadikan sebagai nilai moral untuk landasan dalam menjalani kehidupan bermasyarakat, berbangsa dan bernegara. Prinsip etika Pancasila pada hakikatnya bersifat humanistik, artinya nilai-nilai Pancasila mendasarkan pada nilai yang bersumber pada harkat dan martabat manusia sebagai makhluk yang berbudaya. Pancasila sebagai dasar negara dan ideologi bangsa mengandung nilai ketuhanan, nilai kemanusiaan, nilai persatuan, nilai kerakyatan dan nilai keadilan. Apabila manusia mampu menyadari dan benar-benar bisa menjalankan kelima aturan moral atau kelima nilai yang terkandung dalam Pancasila, maka manusia dapat menyelamatkan bangsa dari berbagai konflik. Membangun karakter melalui nilai-nilai Pancasila dapat mempersatukan seluruh kebhinekaan bangsa Indonesia.

Kata Kunci: Karakter, Nilai-nilai Pancasila, dan Resolusi Konflik 


\section{A. PENDAHULUAN}

Masalah seputar karakter atau moral yang terjadi sekarang ini, jauh lebih banyak dan kompleks dibandingkan dengan masalah-masalah karakter atau moral yang terjadi pada masa-masa sebelumnya. Persoalan karakter menjadi bahan pemikiran sekaligus keprihatinan bersama karena negara ini bisa dianggap sedang mengalami krisis karakter. Krisis ini antara lain ditandai dengan meningkatnya pergaulan seks bebas, penyalahgunaan obat-obatan,

pornografi, maraknya kekerasan anakanak dan remaja, tawuran antar kampung dan sekolah serta perilaku pejabat yang tidak beretika di pemerintahan.

Kajian-kajian ilmiah tentang perilaku tidak terpuji (amoral) yang dilakukan oleh siswa dalam dunia pendidikan di Indonesia sangatlah terbatas. Namun di negara-negara maju seperti di Amerika sudah sangat berkembang, survai nasional yang dilakukan oleh The Ethics Of American Youth, dari Josephson Institute Of Ethics tahun 2006, diketahui bahwa tepat jika dijadikan landasan dalam perilaku siswa dalam jangka waktu 12 bersikap dan berperilaku karena dalam bulan yaitu (a) $82 \%$ mengakui bahwa Pancasila terdapat nilai ketuhanan, nilai mereka berbohong kepada orang tua; (b) $62 \%$ mengakui bahwa mereka berbohong kepada guru; (c) $33 \%$ menjiplak tugas dari internet; (d) $60 \%$ menipu selama pelaksanaan ujian di sekolah; (e) 19\% mencuri sesuatu dari teman; dan (f) $28 \%$ mencuri sesuatu dari toko (Zubaedi, 2012:4). Di negara Indonesia kejadian serupa juga terjadi secara meluas bukan hanya pada kalangan siswa dan masyarakat bahkan menjalar pada pejabat negara dan mahasiswa yang sikap dan perilakunya tidak terpuji..

Kondisi krisis moral ini menandakan bahwa seluruh pengetahuan agama dan pengetahuan moral yang didapatkan di sekolah ternyata belum berdampak terhadap perubahan perilaku manusia Indonesia. Kondisi ini akhirnya menyebabkan banyak pihak menyimpulkan perlunya landasan dalam membangun karakter sehingga masyarakat memiliki pedoman dalam besikap dan berperiku bernegara. Sebagai dasar negara dan ideologi bangsa, Pancasila sangatlah dalam kehidupan berbangsa dan 
kemanusiaan, nilai persatuan, nilai kerakyatan, dan nilai keadilan. Nilainilai Pancasila merupakan sebuah norma untuk menata kehidupan manusia.

Apabila mengimplementasikan nilai-nilai dari Pancasila akan terkandung beberapa hubungan yang melahirkan keseimbangan antara hak dan kewajiban antara hubungan tersebut. Pertama: hubungan vertikal yaitu hubungan manusia dengan Tuhan, sebagai penjelmaan dari nilainilai Ketuhanan Yang Maha Esa. Kedua: hubungan horizontal yaitu hubungan manusia dengan sesamanya baik dalam fungsinya sebagai warga masyarakat, warga bangsa dan warga negara. Hubungan tersebut melahirkan hak dan kewajiban yang seimbang. Ketiga: hubungan alamiah yaitu hubungan manusia dengan alam sekitar yang meliputi hewan, tumbuhtumbuhan dan alam dengan segala kekayaannya.

Pancasila harus menjadi landasan etika dan moral ketika bangsa Indonesia membangun pranata politik, pemerintahan, ekonomi, penegakan hukum, sosial budaya dan berbagai aspek kehidupan lainnya. Pemikiran
Soekarno yang tertuang dalam Pancasila merupakan pemikiran yang paling relevan pada masa kini dan masa depan. Kita jadikan Pancasila sebagai living ideology dalam menyelesaikan segala konflik, sehingga bangsa Indonesia mampu menjadi negara yang maju dan bermartabat.

\section{B. HASIL DAN PEMBAHASAN}

1. Hakikat Membangun Karakter Manusia

Karakter adalah mustika yang membedakan manusia dengan binatang. Manusia tanpa karakter adalah manusia yang sudah membinatang. Orangorang yang berkarakter kuat dan baik secara individual maupun secara sosial ialah mereka yang memiliki akhlak, moral dan budi pekerti yang baik. Menurut Coon, (Zubaedi, 2012:8) mendefinisaikan karakter sebagai suatu penilaian subjektif terhadap kepribadian seseorang yang berkaitan dengan atribut kepribadian yang dapat atau tidak dapat diterima oleh masyarakat. Karakter merupakan keseluruhan disposisi kodrati dan disposisi 
Edutech, Tahun 13, Vol.1, No.3, Oktober 2014

yang telah dikuasai secara stabil yang mendefinisikan seorang individu dalam keseluruahan tata perilaku psikis yang menjadikannya tipikal dalam cara berpikir dan bertindak. Menurut Ekowarni, (Zubaedi, 2012:9) pada tatanan mikro karakter diartikan sebagai (a) kualitas dan kuantitas reaksi terhadap diri sendiri, orang lain, maupun situasi tertentu; dan (b) watak, akhlak dan ciri psikologis.

Sebagai aspek kepribadian karakter merupakan cerminan dari kepribadian secara utuh dari seseorang: mentalitas sikap dan perilaku, Secara universal berbagai karakter dirumuskan sebagai nilai hidup bersama berdasarkan atas pilar kedamaian (peace), menghargai (respect), kerjasama (cooperation) kebebasan

(freedom), kebahagiaan (happiness), kejujuran (honesty), kerendahan hati (humility), kasih sayang (love), tanggung jawab (responsibility), kesederhanaan (simplicity), toleransi (tolerance) dan persatuan (unity). Karakter (character) mengacu pada serangkaian sikap (attitudes), perilaku (behaviors), motivasi (motivations) dan keterampilan (skills).

Membangun karakter diakui jauh lebih sulit dan membutuhkan waktu yang lebih lama. Situasi dan kondisi karakter bangsa yang sedang memprihatinkan telah mendorong pemerintah untuk mengambil inisiatif untuk memprioritaskan pembangunan karakter bangsa. Pembangunan karakter bangsa dijadikan arus utama pembangunan nasional. Hal ini mengandung arti bahwa setiap upaya pembangunan harus selalu diarahkan untuk memberi dampak positif terhadap pengembangan karakter.

Menurut pendapat (Gede Raka, dkk, 2011:105) bahwa dari sudut pandang pembangunan bangsa faktor yang dapat dijadikan dasar pertimbangan dalam 
menentukan

prioritas

pengembangan karakter adalah

(1) kebutuhan menjaga

keutuhan bangsa; (2) kebutuhan

untuk membangun masyarakat

berakhlak mulia; (3) kebutuhan

untuk menjadi bangsa yang

maju; (4) Kebutuhan untuk

meningkatkan kemakmuran

bangsa secara berkelanjutan;

dan (5) kebutuhan untuk

menegakan keadilan. Proses

pembentukan karakter pada

seseorang dipengaruhi oleh

faktor khas yang ada dalam diri

orang yang bersangkutan yang

sering disebut faktor endogen

dan oleh faktor lingkungan atau

yang sering disebut faktor

eksogen. Perlu diingat bahwa

faktor endogen boleh dikatan

sebagai faktor yang berada di

luar jangkauan masyarakat.

Segala sesuatu yang berada

dalam pengaruh kita, baik

sebagai individu maupun bagian

dari masyarakat adalah faktor

lingkungan (eksogen). Secara

normatif, pembentukan atau

pengembangan karakter yang

baik memerlukan kualitas lingkungan yang baik pula.

Sekian banyak faktor

lingkungan yang berperan

dalam pembentukan karakter

yaitu keluarga, media masa,

lingkungan sosial dan sekolah

(Gede Raka, dkk, 2011:105).

Karakter masyarakat

Indonesia sebelum

kemerdekaan terbilang sangat

kuat, hal tersebut dapat terlihat

dari perjuangan para pahlawan

dalam mencapai kemerdekaaan.

Semangat persatuan, rela

berkorban dan tidak putus asa

merupakan karakter yang

dimiliki oleh para pahlawan

sehingga hanya bermodalkan

senjata bambu runcing dapat

membuat penjajah keluar dari

tanah air Indonesia. Sekarang

ini masyarakat Indonesia tidak

sekuat pada masa lalu, sudah

sangat rapuh. Semangat juang

bangsa ini nyaris hilang ditelan

berbagai godaan dan

kepentingan sesaat. Menurut

(Gede Raka, dkk, 2011:120)

kondisi karakter bangsa

Indonesia saat ini dapat

digambarkan sebagai berikut: 
a. Kebiasaan korupsi yang sulit diberantas.

Negara Indonesia masih dikategorikan sebagai salah satu negara yang terkorup diwilayah Asia Pasifik. Semua orang tau bahwa kebiasaan korupasi merupakan manifestasi nyata dari akhlak yang rusak. Namun, banyak orang yang tetap saja melakukan tindakan tercela tersebut. Menjadi sangat mencemaskan bahwa sikap yang menerima korupsi sebagai hal yang tidak bisa dihindari, serta sirnanya perasaan bersalah dan rasa malu pada mereka yang melakukan tindakan korupsi.

b. Lemahnya kedisiplinan

Hal yang sangat memprihatinkan, lebih dari setengah abad sesuadah negara Indonesia merdeka, pendidikan kita belum mampu menghasilkan warganegara Indonesia yang mampu mentaati peraturan. Lebih mencemaskan lagi, ketidaktaatan itu semakin meluas dan makin dianggap sebagai hal yang biasa.

c. Melemahnya jiwa keindonesiaan

$\begin{array}{rr}\text { Kaum } & \text { muda } \\ \text { Indonesia } & \text { makin }\end{array}$
menonjolkan kepentingan daerahnya daripada kepentingan bangsa. Masyarakat Indonesia seperti kehilangan citacita bersama yang bisa mengikatnya sebagai bangsa yang kokoh, masyarakat kita lebih menonjolkan cita-cita golongan untuk mengalahkan golongan lain.

d. Menurunnya kemampuan untuk menerima dan menghargai perbedaan Aktualisasi semangat Bhinneka Tunggal Ika 
yang ada di Pancasila

belum dapat dilakukan

secara optimal. Hal

tersebut terliahat dari

semakin banyaknya

tindakan kekerasan atau

pemaksaan kehendak

yang dilakukan oleh suatu

kelompok terhadap

kelompok lain yang

dianggap berbeda, apalagi

jika kelompok yang

berbeda ini dinilai lebih

lemah.

e. Kurangnya

rasa

keterdesakan

Sudah banyak

wacana mengenai

pentingnya perubahan

yang disampaikan oleh

para pejabat, namun

perubahan yang

diharapkan tidak kunjung

terwujud atau dirasakan

berjalan terlambat. Salah

satu penyebab terjadinya keadaan seperti ini adalah

kurangnya rasa

keterdesakan.

f. Kesenjangan antara yang diketahui dan yang dilakukan

Banyak orang yang tau tentang perilaku dan sikap yang baik, namun melakukannya dalam kehidupan sehari-hari sebaliknya. Jadi, ada kesenjangan antara yang dikatakan dengan yang dilakukan.

Melihat fenomena yang terjadi seperti di atas, maka secara khusus nilai yang harus dikembangkan berdasarkan (Kementerian Pendidikan Nasional Badan Penelitian dan Pengembangan

Kurikulum, 2009:9-10) yaitu:

Tabel 1

Nilai dan Deskripsi Nilai Karakter

\begin{tabular}{|l|l|}
\hline \multicolumn{2}{|c|}{ Nilai } \\
\hline 1. Religius & $\begin{array}{l}\text { Sikap dan perilaku yang patuh dalam melaksanakan } \\
\text { ajaran agama yang dianutnya, toleransi terhadap } \\
\text { pelaksanaan ibadah agama lain dan hidup rukun dengan }\end{array}$ \\
\hline
\end{tabular}

331 Membangun Karakter Mahasiswa Berbasis Nilai-Nilai Pancasila Sebagai Resolusi Konflik 


\begin{tabular}{|c|c|}
\hline & pemeluk agama lain. \\
\hline 2. Jujur & $\begin{array}{l}\text { Perilaku yang didasarkan pada upaya menjadikan dirinya } \\
\text { sebagai orang yang selalu dapat dipercaya dalam } \\
\text { perkataan, tindakan dan pekerjaan }\end{array}$ \\
\hline 3. Toleransi & $\begin{array}{l}\text { Sikap dan tindakan yang menghargai perbedaan agama, } \\
\text { suku, etnis, pendapat, sikap, dan tindakan orang lain } \\
\text { yang berbeda dari dirinya }\end{array}$ \\
\hline 4. Disiplin & $\begin{array}{l}\text { Tindakan yang menunjukan perilaku tertib dan patuh } \\
\text { pada berbagai ketentuan dan peraturan }\end{array}$ \\
\hline 5. Kerja Keras & $\begin{array}{l}\text { Perilaku yang menunjukan upaya sungguh-sungguh } \\
\text { dalam mengatasi berbagai hambatan belajar dan tugas } \\
\text { serta menyelesaikan tugas dengan sebaik-baiknya }\end{array}$ \\
\hline 6. Kreatif & $\begin{array}{l}\text { Berpikir dan melakukan sesuatu untuk menghasilkan } \\
\text { cara atau hasil baru dari sesuatu yang telah dimiliki }\end{array}$ \\
\hline 7. Mandiri & $\begin{array}{l}\text { Sikap dan perilaku yang tidak mudah tergantung pada } \\
\text { orang lain dalam menyelesaikan tugas-tugas }\end{array}$ \\
\hline 8. Demokratis & $\begin{array}{l}\text { Cara berfikir, bersikap dan bertindak yang menilai sama } \\
\text { hak dan kewajiban dirinya dan orang lain }\end{array}$ \\
\hline 9. Rasa ingin tahu & $\begin{array}{l}\text { Sikap dan tindakan yang selalu berupaya untuk } \\
\text { mengetahui lebih mendalam dan meluas dari sesuatu } \\
\text { yang dipelajari, dilihat dan didengar }\end{array}$ \\
\hline $\begin{array}{l}\text { 10. Semangat } \\
\text { Kebangsaan }\end{array}$ & $\begin{array}{l}\text { Cara berpikir, bertindak, dan berwawasan yang } \\
\text { menempatkan kepentingan bangsa dan negara diatas } \\
\text { kepentingan diri dan kelompoknya }\end{array}$ \\
\hline 11. Cinta tanah air & $\begin{array}{l}\text { Cara berpikir, bersikap dan berbuat yang menunjukan } \\
\text { kesetiaan, kepedulian dan penghargaan yang tinggi } \\
\text { terhadap bahasa, lingkungan fisik, social, budaya, } \\
\text { ekonomi dan politik bangsa }\end{array}$ \\
\hline $\begin{array}{l}\text { 12. Menghargai } \\
\text { prestasi }\end{array}$ & $\begin{array}{l}\text { Sikap dan tindakan yang mendorong dirinya untuk } \\
\text { menghasilkan sesuatu yang berguna bagi masyarakat dan } \\
\text { mengakui serta menghormati keberhasilan orang }\end{array}$ \\
\hline $\begin{array}{l}\text { 13. Bersahabat/ } \\
\text { komunikatif }\end{array}$ & $\begin{array}{l}\text { Tindakan yang memperlihatkan rasa senang berbicara, } \\
\text { bergaul dan bekerja sama dengan orang lain }\end{array}$ \\
\hline 14. Cinta damai & $\begin{array}{l}\text { Sikap, perkataan dan tindakan yang menyebabkan orang } \\
\text { lain merasa senang dan aman atas kehadiran dirinya }\end{array}$ \\
\hline $\begin{array}{l}\text { 15. Gemar } \\
\text { membaca }\end{array}$ & $\begin{array}{l}\text { Kebiasaan menyediakan waktu untuk membaca berbagai } \\
\text { bacaan yang memberikan kebajikan bagi dirinya. }\end{array}$ \\
\hline $\begin{array}{ll}\text { 16. } & \text { Peduli } \\
\text { lingkungan }\end{array}$ & $\begin{array}{l}\text { Sikap dan tindakan yang selalu berupaya mencegah } \\
\text { kerusakan pada lingkungan alam disekitarnya dan } \\
\text { mengembangkan upaya-upaya untuk memperbaiki } \\
\text { kerusakan alam yang sudah terjadi }\end{array}$ \\
\hline 17. Peduli sosial & $\begin{array}{l}\text { Sikap dan tindakan yang selalu ingin member bantuan } \\
\text { kepada orang lain dan masyarakat yang membutuhkan }\end{array}$ \\
\hline 18. Tanggungjawab & $\begin{array}{l}\text { Sikap dan perilaku seseorang untuk melaksanakan tugas } \\
\text { dan kewajiban yang seharusnya dilakukan terhadap diri }\end{array}$ \\
\hline
\end{tabular}

332 Membangun Karakter Mahasiswa Berbasis Nilai-Nilai Pancasila Sebagai Resolusi Konflik 

YME

Pengembangan nilai-nilai
karakter tentunya harus
disesuakan dengan kebutuhan.
Dengan demikian, dalam
pengembangan nilai-nilai
karakter dapat menambah
ataupun mengurangi sesuai
dengan kebutuhan, tujuan dan
targetan dalam
masyarakat atau lembaga-
lembaga tertentu.

2. Hakikat Nilai Sila-Sila Pancasila

Tentang hakikat sila-sila Pancasila perlu ditengarai makna dan arti dari setiap sila Pancasila secara hakiki agar mendapatkan gambaran tentang inti arti Pancasila. Maka, sudah tepat hanya lima sila itu yang dimasukan dalam dasar filsafat negara sebagai inti kesamaan dari segala keadaan yang beraneka warna dan juga telah mencukupi, dalam arti tidak ada lainnya yang tidak dapat dikembalikan kepada salah satu sila Pancasila. Notonegoro (Pandji Setijo, 2010:18).

Sila Pertama; Ketuhanan Yang Maha Esa. Mengandung pengertian dan keyakinan adanya Tuhan YME, pencipta alam semesta beserta isinya. Negara Kesatuan Republik Indonesia (NKRI) ditegaskan meskipun bukan negara agama, bukan juga negara sekuler melainkan adalah negara beragama. Bukan negara agama karena tidak menerapkan hukum agama tertentu sebagai hukum positif. Bukan pula negara sekuler yang memisahkan urusan negara dan urusan agama, sedangkan negara beragama dimaksud bahwa NKRI perlu hukum positif yang disepakati oleh seluruh bangsa, termasuk seluruh penyelenggara negara yang agamanya beraneka ragam dan negara wajib melindungi segenap agama yang diakui serta negara tidak dibenarkan 
Edutech, Tahun 13, Vol.1, No.3, Oktober 2014

mencampuri urusan akidah agama apapun.

Sila Kedua; Kemanusiaan yang adil dan beradab. Kemanusiaan berasal dari kata manusia yaitu manusia berbudi yang memiliki potensi pikir, rasa, karsa dan cipta karena berpotensi menduduki martabat yang tinggi. Adil mengandung arti bahwa suatu keputusan dan tindakan didasarkan atas normanorma yang objektif, tidak subjektif apalagi sewenangwenang dan otoriter. Beradab berasal dari kata adab, memiliki arti budaya yang telah berabadabad dalam kehidupan manusia. Jadi beradab berarti berkebudayaan yang lama berabad-abad, bertata kesopanan, dan bermoral.

Sila Ketiga; Persatuan Indonesia. Persatuan berasal dari kata satu berarti utuh tidak terpecah-belah, mengandung bersatunya bermacam corak yang beraneka ragam yang bersifat kedaerahan menjadi satu kebulatan secara nasional. Selain itu, persatuan bangsa $\begin{array}{lrr}\text { yang bersifat } & \text { nasional } \\ \text { mendiami } & \text { suatu } & \text { wilayah } \\ \text { Indonesia, } & \text { bersatu } & \text { menuju } \\ \text { kehidupan } & \text { bangsa } & \text { yang }\end{array}$ berbudaya bebas dalam wadah negara kesatuan rebublik Indonesia yang merdeka dan berdaulat menuju terbentuknya suatu masyarakat madani.

Sila Keempat; Kerakyatan yang dipimpin oleh hikmat kebijaksanaan dalam permusyawaratan perwakilan. Sila ini mengandung arti bahwa rakyat dalam NKRI menjalankan keputusannya dengan jalan musyawarah yang dipimpin oleh pikiran yang sehat serta penuh tanggungjawab dari para pemimpin yang profesional, baik kepada Tuhan YME maupun kepada rakyat yang diwakilinya.

Sila Kelima; Keadilan sosial bagi seluruh rakyat Indonesia. Keadilan sosial berarti keadilan yang berlaku dalam masyarakat segenap bidang kehidupan. Seluruh rakyat Indonesia berarti setiap 
orang yang menjadi rakyat Indonesia baik yang berada di dalam maupun di luar negeri. Jadi, setiap bangsa Indonesia mendapat perlakuan yang adil dibidang hukum, politik, social, ekonomi dan budaya.

Pancasila secara bulat dan utuh sangat sesuai menjadi milik bangsa Indonesia sebagai dasar dan ideologi negara. Setiap warganegara Indonesia wajib memahami makna dari sila-sila pancasila dan menjadikan nilai-nilai pancasila sebagai landasan bersikap dan berperilaku dalam kehidupan bermasyarakat, berbangsa dan bernegara.

Secara ringkas (Yudi Latif, 2011) menguraikan pokokpokok moralitas dan haluan kebangsaan kenegaraan menurut alam Pancasila sebagai berikut: Pertama; munurut alam pemikiran Pancasila, nilai-nilai ketuhanan (religiusitas) sebagai sumber etika dan spiritualitas dianggap penting sebagai fundamentaletika kehidupan bangsa. Kedua; menurut alam pemikiran Pancasila, nilai nilai kemanusiaan universal yang bersumber dari hukum Tuhan, hukum alam, dan sifat-sifat sosial manusia (yang bersifat horizontal) dianggap penting sebagai fundamental etika politik kehidupan bernegara dalam pergaulan dunia. Landasan etika sebagai prasarat persaudaraan universal ini adalah adil dan beradab.

Ketiga; menurut alam pemikiran Pancasila, aktualisasi nilai-nilai etis kemanusiaan itu terlebih dahulu harus mengakar kuat dalam lingkungan pergaulan kebangsaan yang lebih dekat sebelum menjangkau pergaulan dunia yang lebih jauh. menurut alam pemikiran Pancasila, Persatuan dari kebhinnekaan masyarakat Indonesia dikelola berdasarkan konsepsi kebangsaan yang mengekspresikan persatuan dalam keragaman, dan keragaman dalam persatuan yang dalam slogan negara dinyatakan dalam ungkapan Bhinneka Tunggal Ika. 
Keempat; menurut alam

pemikiran Pancasila, nilai ketuhanan, nilai kemanusiaan dan cita-cita kebangsaan itu dalam aktualisasinya harus menjunjung tinggi kedaulatan rakyat dalam semangat permusyawaratan yang dipimpin oleh hikmat kebijaksanaan. Kelima; menurut alam pemikiran Pancasila, dalam visi keadilan sosial menurut Pancasila yang dikehendaki adalah keseimbangan antara pemenuhan kebutuhan jasmani dan rohani, keseimbangan antara peran manusia sebagai mahluk individu, mahluk sosial, juga keseimbangan atara pemenuhan hak sipil dan politik dengan hak ekonomi, sosial dan budaya.

3. Karakter Sebagai Dasar Resolusi Konflik

Konflik merupakan suatu bentuk interaksi sosial ketika dua individu mempunyai kepentingan yang berbeda dan kehilangan keharmonisan diantara mereka. Konflik sosial yang terjadi di Indonesia telah menyentuh perasaan manusia dan membangkitkan kecemasan serta ketakutan karena konflikkonflik tersebut cenderung bersifat destruktif dan menyebabkan kesengsaraan banyak orang.

Situasi konflik sudah merambah dalam kehidupan kantor atau kampus karena konflik merupakan bagian dari hidup kita, Konflik yang tidak terselesaikan tentunya akan berdampak yang tidak baik. Konflik merupakan sebuah ketidaksepahaman antara dua orang/pihak yang menganggu produktifitas efesiensi dan hasil kerja. Itu jika diartikan dalam lingkup pekerjaan tapi dalam pergaulan sehari-hari, konflik adalah sebuah ketidaksepahaman antara dua orang/pihak yang menganggu kehidupan sehari-hari.

Fenomena kekerasan yang terjadi di kampus bisa dipandang sebagai gunung es, karena umumnya yang terekspos adalah berbentuk 
Edutech, Tahun 13, Vol.1, No.3, Oktober 2014

kekerasan langsung yang nampak dalam kekerasan fisik dan kolektif. Memang terdapat beberapa faktor yang menjadi pemicu kekerasan tersebut. Akan tetapi seringkali kekerasan merupakan muara dari terjadinya konflik yang tertangani secara keliru. Menurut Galtung (Sutanto, 2005:16), konflik merupakan penyebab niscaya bagi kekerasan, karena di bawah atau di balik setiap bentuk kekerasan terdapat konflik yang belum terselesaikan.

Dia mengumpamakan kekerasan adalah asap dan konflik adalah apinya.

Konflik terjadi akibat situasi dimana keinginan atau kehendak yang berbeda atau berlawanan antara satu dengan yang lain,sehingga salah satu atau keduanya saling terganggu. Konflik merupakan suatu kondisi terjadinya ketidakcocokan antara nilai atau tujuan-tujuan yang ingin dicapai baik yang ada dalam diri individu maupun dalam hubungannya dengan orang lain. Kondisi yang telah dikemukakan tersebut dapat mengganggu bahkan menghambat tercapainya emosi atau stres yang mempengaruhi efisiensi dan produktifitas kerja. Pandangan dari Pickering (Anastasia Priliantini, 2008) konflik adalah persaingan atau pertentangan antara pihak-pihak yang tidak cocok satu sama lain keadaan atau perilaku yang bertentangan, misalnya pertentangan pendapat, kepentingan, atau pertentangan antar individu; perselisihan akibat kebutuhan, dorongan, keinginan atau tuntutan yang bertentangan, perseteruan.

Sehubungan dengan konflik yang pernah dan akan terjadi pada setiap individu, ternyata tidak semua individu memiliki sikap dan kecakapan menyelesaikan konflik secara positif. Selama ini kecenderungan seseorang menggunakan beberapa cara tertentu untuk memecahkan konflik seperti: menyerah 
begitu saja dengan segala kerendahan hati, melarikan diri dari persoalan yang mengakibatkan konflik, membalas musuh dengan kekuatan dan kekerasan yang jauh lebih dahsyat, menuntut melalui jalur hukum, dan sebagainya. Ternyata cara-cara tersebut sering tidak efektif dan selalu ada yang menjadi korban.

Resolusi konflik adalah suatu proses analisis dan penyelesaian masalah yang mempertimbangkan kebutuhankebutuhan individu dan kelompok seperti identitas dan pengakuan juga perubahanperubahan institusi yang diperlukan untuk memenuhi kebutuhan. Konflik terkadang dapat saja diselesaikan oleh kedua belah pihak yang bertikai secara langsung. Namun tak jarang pula harus melibatkan pihak ketiga untuk menengahi dan mencari jalan keluar baik oleh negara atau Organisasi Regional bahkan Organisasi Internasional. Manajemen konflik merupakan serangkaian aksi dan reaksi antara pelaku maupun pihak luar dalam suatu konflik. Manajemen konflik termasuk pada suatu pendekatan yang berorientasi pada proses yang mengarahkan pada bentuk komunikasi (termasuk tingkah laku) dari pelaku maupun pihak luar dan bagaimana mereka mempengaruhi kepentingan (interests) dan interpretasi. Bagi pihak luar (di luar yang berkonflik) sebagai pihak ketiga, yang diperlukannya adalah informasi yang akurat tentang situasi konflik. Hal ini karena komunikasi efektif di antara pelaku dapat terjadi jika ada kepercayaan terhadap pihak ketiga.

Selanjutnya Brooks dan Gooble (Petrus Irianto, 2011:73) mengatakan bahwa sudah seharusnya melaksanakan pendidikan karakter sebagai tindakan preventif yang tepat dalam resolusi konflik, maka ada tiga elemen penting yang harus diperhatikan yaitu (1) prinsip; (2) proses; dan (3) prakteknya dalam pengajaran. 
Dalam menjalankan prinsip tersebut maka nilai-nilai yang diajarkan harus

termanifestasikan dalam kurikulum sehingga semua mahasiswa paham benar tentang nilai-nilai tersebut dan mampu menerjemahkan dalam perilaku nyata.

4. Kerangka (Design) Membengun Karakter Mahasiswa berbasis Nilai-nilai Pancasila Membangun karakter mahasiswa dilakukan dengan tiga pendekatan yaitu program kurikuler (perkuliahan) dan kokurikuler ; (2) program ektrakurikuler fakultas, jurusan dan prodi; 3) Program ektrakurikuler ormawa universitas. Membangun karakter mahasiswa berbasis nilai-nilai Pancasila membutuhkan terlibatan semua elemen bangsa dari orang tua, dosen, tokoh masyarakat, tokoh ormas dan tokoh agama. Mewujudkan mahasiswa yang berkarakter baik perlu didukung juga iklim lingkungan kampus yang baik dan lembaga-lebaga lain di luar kampus untuk memperkokoh kepribadian mahasiswa. Nilai-nilai karakter yang dikembangakan merupakan nilai-nilai yang menjadi pembiasaan dalam kehidupan sehari-hari.

Pancasila sebagai dasar negara dan ideologi bangsa berisi lima sila yang pada hakikatnya berisi lima nilai dasar yang fundamental. Nilainilai dasar dari pancasila tersebut adalah nilai Ketuhanan Yang Maha Esa, Nilai Kemanusiaan Yang Adil dan Beradab, nilai Persatuan Indonesia, nilai Kerakyatan yang dipimpin oleh hikmat kebijaksanaan dalan permusyawaratan/perwakilan, dan nilai Keadilan sosial bagi seluruh rakyat Indonesia.

Nilai-nilai Pancasila yang akan menjadi dasar pengembangan karakter mahasiswa dijabarkan sebagai berikut: 
Tabel 2

Nilai dan Deskripsi Nilai Karakter Pancasila

\begin{tabular}{|l|l|}
\hline \multicolumn{1}{|c|}{ Nilai } & \multicolumn{1}{c|}{ Deskripsi } \\
\hline Ketuhanan & $\begin{array}{l}\text { Pengakuan dan keyakinan terhadap Tuhan YME. Dengan nilai } \\
\text { ini menyatakan bangsa Indonesia merupakan bangsa yang } \\
\text { religius dan manusia arus taat terhadap ajaran agama yang } \\
\text { diyakininya. }\end{array}$ \\
\hline Kemanusiaan & $\begin{array}{l}\text { Kesadaran sikap dan perilaku sesuai dengan nilai-nilai moral } \\
\text { dalam hidup bersama atas dasar tuntutan hati nurani dengan } \\
\text { memperlakukan sesuatu hal sebagaimana mestinya. }\end{array}$ \\
\hline Persatuan & $\begin{array}{l}\text { Usaha ke arah bersatu dalam kebulatan rakyat untuk membina } \\
\text { asa nasionalisme dan sekaligus mengakui dan menghargai } \\
\text { sepenuhnya terhadap keanekaragaman masyarakat Indonesia.. }\end{array}$ \\
\hline Kerakyatan & $\begin{array}{l}\text { Mengembangkan musyawarah mufakat dan nilai-nilai } \\
\text { demokrasi. }\end{array}$ \\
\hline Keadilan & $\begin{array}{l}\text { Suatu kesadaran bersama mewujudkan keadilan bagi diri dan } \\
\text { sesama manusia. }\end{array}$ \\
\hline
\end{tabular}

Grand design Membangun karakter mahasiswa berbasis nilai-nilai Pancasila dapat digambarkan sebagai berikut:

Bagan 1

Grand Design Membangun Karakter Mahasiswa

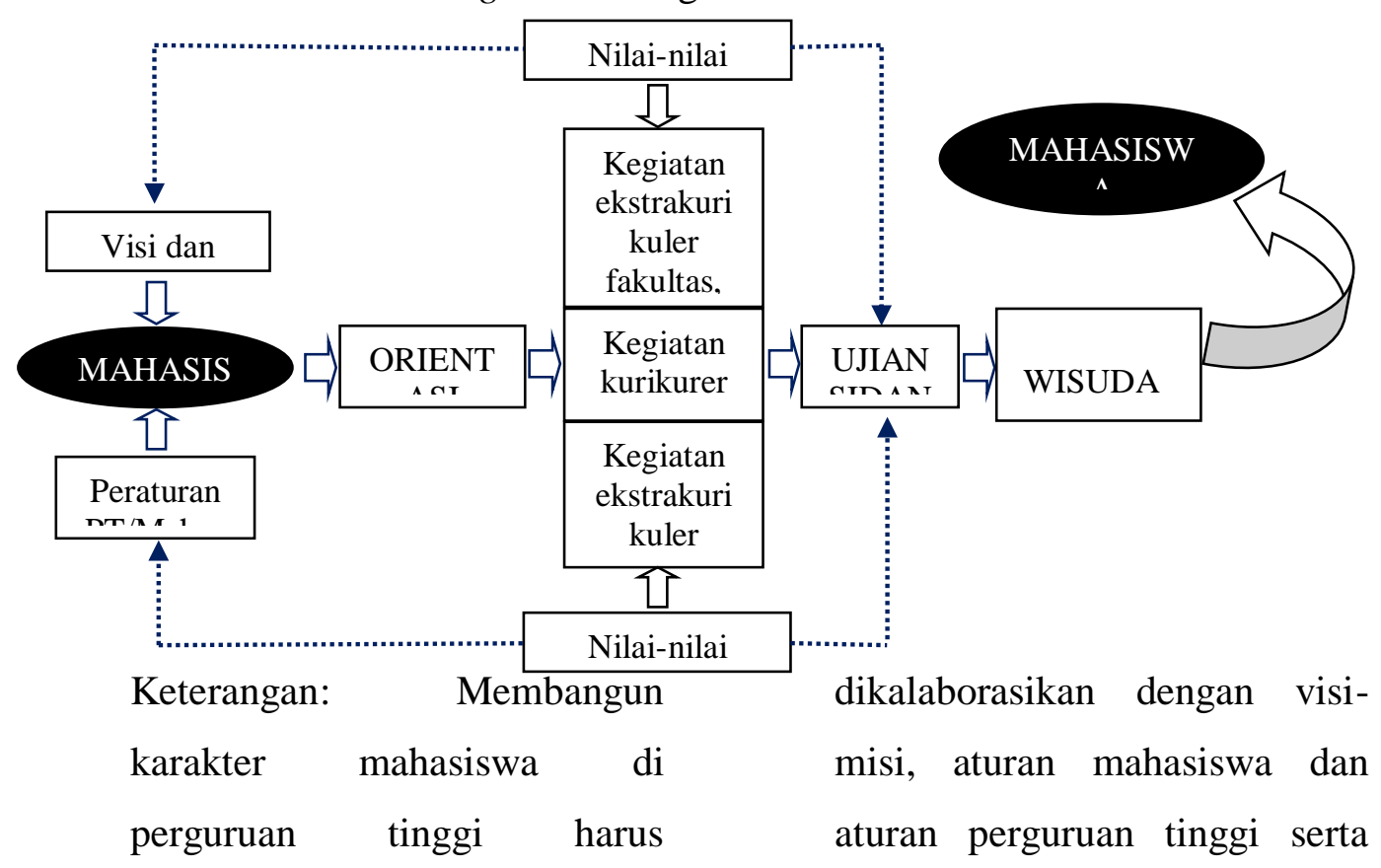

340 Membangun Karakter Mahasiswa Berbasis Nilai-Nilai Pancasila Sebagai Resolusi Konflik 
kegiatan-kegiatan

kemahasiswaan baik yang sifatnya program kurikuler ataupun ekstrakurikuler dan dilakukan sepanjang tahun secara terprogram sampai mahasiswa tersebut lulus dari perguruan tinggi.

\section{SIMPULAN}

Membangun karakter pada mahasiswa di perguruan tinggi sangat penting sebagai kelanjutan pendidikan karakter di sekolah. Membangun karakter diperguruan tinggi tidak cukup dilakukan melalui kegiatan kurikuler tetapi juga harus dilakukan melalui kegiatan kokurikuler dan ekstrakurikuler. Membangun karakter di perguruan tinggi harus berpijak kepada nilai-nilai karakter dasar, yang selanjutnya dikembangkan sesuai dengan kebutuhan, kondisi, dan lingkungan kampus itu sendiri. Pancasila sebagai dasar negara dan idiologi bangsa yang berintikan nilai ketuhanan, nilai kemanusiaan, nilai persatuan, nilai kerakyatan dan nilai keadilan dirasa tepat jika dijadikan sebagai dasar membangun karakter mahasiswa. Pancasila mengandung nilai-nilai yang sesuai dengan kondisi kebangsaan dalam menghadapi tantangan dan mencerminkan karakteristik bangsa. Dengan demikian, nilai-nilai Pancasila dijadikan sebagai norma dalam mengatasi segala persoalan dalam kehidupan bermasyarakat berbangsa dan bernegara.

\section{DAFTAR PUSTAKA}

Irianto, Petrus. (2011). Pola Interaksi Konflik Dan Reaktualisasi Pendidikan Karakter. Bandung: Tesis Program studi PKn SPs UPI.

Kementerian Pendidikan Nasional. (2009). Pengembangan Pendidikan Budaya dan Karakter Bangsa. Jakarta: Kementerian Pendidikan Nasional Badan Penelitian dan Pengembangan Kurikulum.

Latif, Yudi (2011). Pancasila dasar dan Haluan Negara, Makalah dalam Lokakarya Empat Pilar Kehidupan Berbangsa dan Bernegara. Jakarta: MPR RI, 1719 Juni 2011.

Raka, Gede, dkk. (2011). Pendidikan Karakter di Sekolah dari Gagasan ke Tindakan. Jakarta: PT Gramedia 
Setijo, Pandji. (2010). Pendidikan Pancasila Perspektif Sejarah Perjuangan Bangsa. Jakarta: PT Gramedia Widiasarana Indonesia. Sutanto, L. (2005). Teori Konseling dan Psikotherapi Perdamaian. (Thesis). Malang : PPS UM.

Priliantini, Anastasia. (2008). Hubugan antara gaya manajemen konflik dengan kecenderungan perilaku agresif narapidana usia remaja di lapas anak pria tangerang. Jurnal Psiko Edukasi Vol 6, Mei 2008.

Zubaedi. (2012). Desain Pendidikan Karakter Konsep dan Aplikasinya dalam Lembaga Pendidikan. Jakarta: Kencana Prenada Media Group. 